\title{
USE OF AEROGEL IN CEMENTITIOUS MATRICES FOR LIGHTWEIGHT CONSTRUCTION: A SYSTEMATIC REVIEW
}

\author{
Ariely Santana de Oliveira ${ }^{a}$, Moisés Ferreira Eleutério Silva ${ }^{b,}$, Lilian Lefol Nani \\ Guarieiro $^{c}$ \\ a,b Civil Construction, SENAI CIMATEC, Brazil, \\ c Chemical, Petrochemical and Computational Modelling, SENAI CIMATEC, Brazil
}

\begin{abstract}
A growing effort for lightweight constructions, such as temporally shelters, and emergency will be a trend in the post-COVID-19 scenario. In this context, a systematic review was developed on the performance of the use of aerogel in the cementitious matrix for prefabricating constructions. A set of academic platforms and keywords were used to investigate articles over the past 6 years. In total, a database was created with 145 files, of which 50 were relevant to the research. Among the works, the results showed densities were between 65 to $230 \mathrm{~kg} / \mathrm{m}^{3}$, thermal conductivity 15 to $28 \mathrm{~mW} /(\mathrm{m} . \mathrm{K})$ and compressive strength from 3 to $23.6 \mathrm{MPa}$. There is a greater tendency for the use of aerogel for thermal comfort and lightness, to the detriment of permeability and mechanical resistance.
\end{abstract}

Keywords: Aerogel; Lightweight materials; Cement matrices.

\section{USO DE AEROGEL EM MATRIZES CIMENTÍCIAS PARA CONSTRUÇÕES LEVES: UMA REVISÃO SISTEMÁTICA}

Resumo: Um esforço crescente na busca por construções mais leves, como abrigos temporários e emergenciais será uma tendência no cenário pós-COVID-19. Foi desenvolvida uma revisão sistemática sobre o desempenho do uso de aerogel em matriz cimentícia para construções pré-fabricadas. Um conjunto de plataformas acadêmicas e palavras-chave foram usadas para investigar artigos nos últimos 6 anos. Dentre os 145 arquivos, apenas 50 foram relevantes para a pesquisa. Entre os

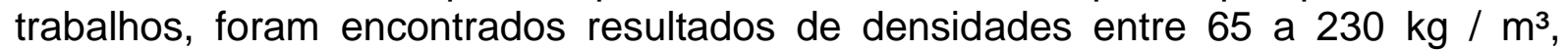
condutividade térmica de 15 a 28 mW / (m.K) e resistência à compressão de 3 a 23,6 $\mathrm{MPa}$. Percebe-se uma maior tendência para o uso de aerogel para conforto térmico e leveza, em detrimento da permeabilidade e resistência mecânica.

Palavras-chave: Aerogel; Materiais leves; Matrizes cimentícias. 


\section{INTRODUCTION}

The uncertainties regarding the situation in which the world will find itself in the post-pandemic period has been causing changes in custom in all industrial segments. In the field of civil construction, the need for increasingly agile construction models has become more evidence, mainly based on the modularization of lighter prefabricated parts.

In this perspective, China was one of the great examples, in carrying out, in just 10 days, the construction of a field hospital to combat of COVID-19, based on modular offsite prefabricated pieces. In Wuhan, the chinese epicenter city to the virus [1, 2, 3], the hospital, which covers approximately 25 thousand square meters [2], was built using techniques and light prefabricated products "(...) following the model at Xiaotangshan Hospital, built in Beijing in just seven days during the SARS epidemic in 2003, and which was instrumental in controlling and treating the outbreak " [1].

In addition to the current scenario, there is an increase in anthropic and natural disasters in Brazil that have caused loss of assets in several cities. Therefore, the need for temporary solutions and emergency buildings becomes a challenge to guarantee an answer to the problems presented. In general, it can be said that there are still great opportunities for new researches aimed to break some paradigms and changes the construction processes.

Moreover, there are many possibilities for producing lighter concretes, mortars and panels, using less dense raw and renewable materials, in order to ensure sustainability and improve in transport logistics and in assembly on the construction site. However, to meet the assumptions of modularization and prefabrication, the correct selection of materials and inputs to be used is essential, above all, verifying whether their structural performance, thermal-acoustic and tightness meet the new requirements of NBR 15575: 2013 [4].

Among the light aggregates already known in Brazil, there is a diversity of products, whether natural or artificial, such as expanded clay [5], vermiculite [6] and perlite [7] which have been widely used in the manufacture of light concrete mainly for insulation applications. However, a new material has gained the attention of the scientific community over the last years, the aerogel. The material was invented by Samuel Stephens Kistler around 1931 and has combination of two words (air + gel) that basically define its generic composition. At first, it appears to be like any other solid translucent material, however, when performing a little deeper analysis, it can be noted that it has slightly different characteristics. Researchers have found that the aerogel maintains its solid structure while having a porosity value $>90 \%$ [8]. Due to the high presence of pores, when compared to other materials, this compound has low density and thus, versatile applications. However, its large-scale are still issues to tackle by the industry, due to cost-production and labor infrastructure.

Therefore, this article aims to develop a systematic review of the use of aerogel in civil construction industry. Therefore, it was investigated the main characteristics and properties of aerogel according to the most relevant research of the last 6 years, the advantages and disadvantages and applications in cementitious matrices. 


\section{METHODOLOGY}

Firstly, articles were selected within the last 6 years (2015 - 2020) regarding to recent market niche, except for patent groups. It was used an interactive process of academic searching platforms/engines such as (SciELO), (ScienceDirect), (CAPES Journal Portal), (National Institute of Industrial Property) and (European Patent Office).

In order to limit the results to publications with a higher level of correspondence, it was used different combinations of keywords such as aerogel, mortar, concrete, lightweight mortar, lightweight concrete, cementitious, cement matrices, cement, cement composites, lightweight cementitious composites, lightweight panels, and lightweight aggregates.

\section{RESULTS AND DISCUSSION}

In Table 1 the keywords were defined through combinations, to delimit results to publications with a higher level of correspondence. It was found a total of 13,475 files related to aerogel.

Table 1 - Data survey based on keywords and search period (2015 - 2020).

\begin{tabular}{lccccc}
\hline \multicolumn{1}{c}{ Keywords } & SciELO & ScienceDirect & $\begin{array}{c}\text { Portal Periódicos } \\
\text { (CAPES) }\end{array}$ & INPI & EPO \\
\hline Aerogel and Mortar & 0 & 688 & 453 & 0 & 1502 \\
Aerogel and Concrete & 0 & 731 & 419 & 0 & 2309 \\
Aerogel and (Lightweight Mortar) & 0 & 195 & 116 & 0 & 10 \\
Aerogel and (Lightweight Concrete) & 0 & 282 & 155 & 0 & 83 \\
Aerogel and Cementitious & 0 & 113 & 112 & 0 & 312 \\
Aerogel and Cement & 0 & 616 & 382 & 0 & 2600 \\
Aerogel and (Cement Matrices) & 0 & 140 & 67 & 0 & 2 \\
Aerogel and (Cement Composites) & 0 & 488 & 255 & 0 & 7 \\
Aerogel and (Lightweight Cementitious Composites) & 0 & 57 & 45 & 0 & 0 \\
Aerogel and (Lightweight Panels) & 0 & 396 & 185 & 0 & 5 \\
Aerogel and (Lightweight Aggregates) & 0 & 474 & 187 & 0 & 89 \\
\hline \multicolumn{1}{c}{ Total } & $\mathbf{0}$ & $\mathbf{4 1 8 0}$ & $\mathbf{2 3 7 6}$ & $\mathbf{0}$ & $\mathbf{6 9 1 9}$ \\
\hline \multicolumn{1}{c}{} & & & & \\
\hline
\end{tabular}

Fonte: Author's own

As can be seen at Table 1 and Graph 1 (below), many documents were found, so it was necessary to apply new selection criteria, demarcating peer-reviewed journals. In this way, works with greater value and academic guarantee were filtered, reducing the amount to 329 files. Subsequently, it was eliminated duplicate files, which generated a database with a total of 145 documents, of which only 50 were selected aleatory and verified in greater depth for this article. 
Graphic 1. Quantitative Distribution - Categorical proportion of publications found throughout 2015-2020.

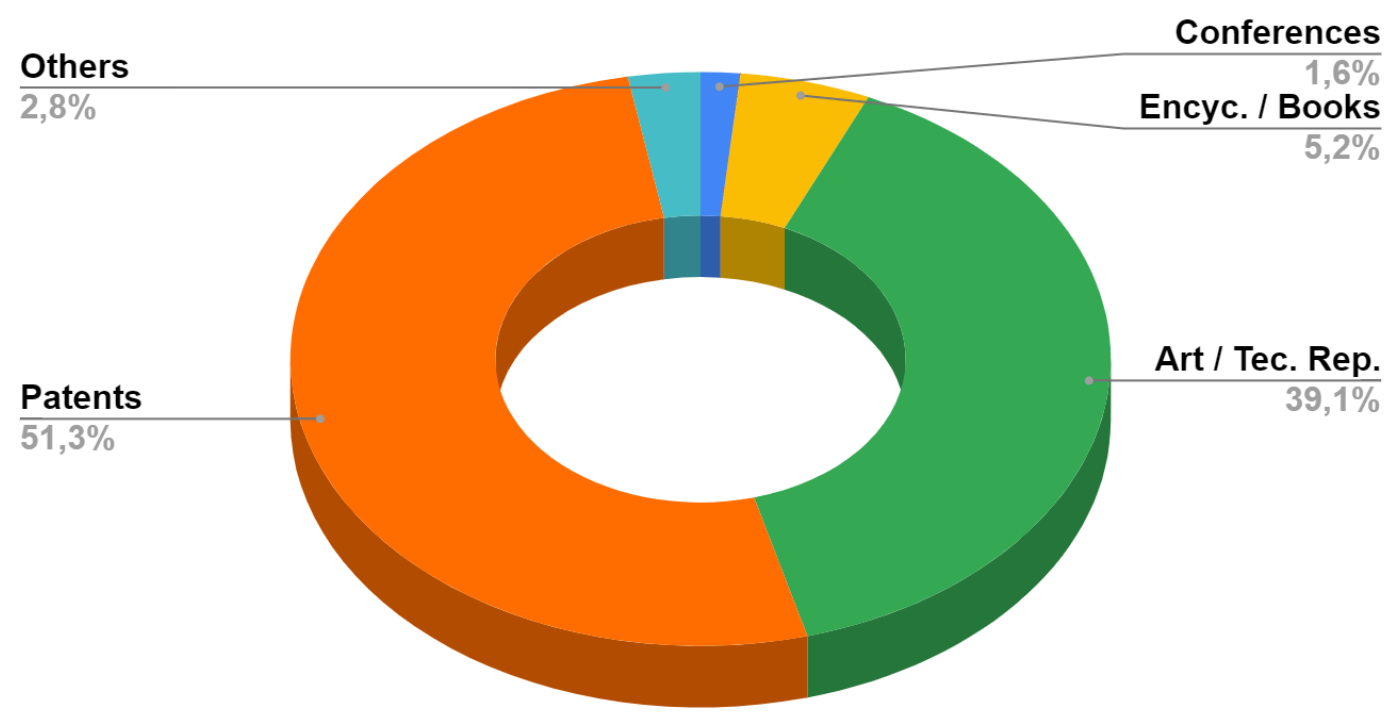

Fonte: Author's own

The surveyed database (50) was explored in a qualitative way, seeking to obtain within the scientific articles about properties of aerogel in matrix cementitious over the last 6 years (2015 - 2020). Thus, it was identified that of the total, only 17 had at least one of the desired information and the other 33 did not meet these requirements. Therefore, timely analyzes will be presented in the next topic.

Within the totality of articles evaluated, it was found that the most advanced countries in studies on aerogel, within the scope of civil construction, as shown in Graph 2, were: Italy with $20.8 \%$ and then Switzerland with $16.7 \%$ of production. Brazil is in the last position, with no evidence of publication throughout the scientific mapping.

Graphic 2. Percentage of countries in article publications between 2015 and 2020.

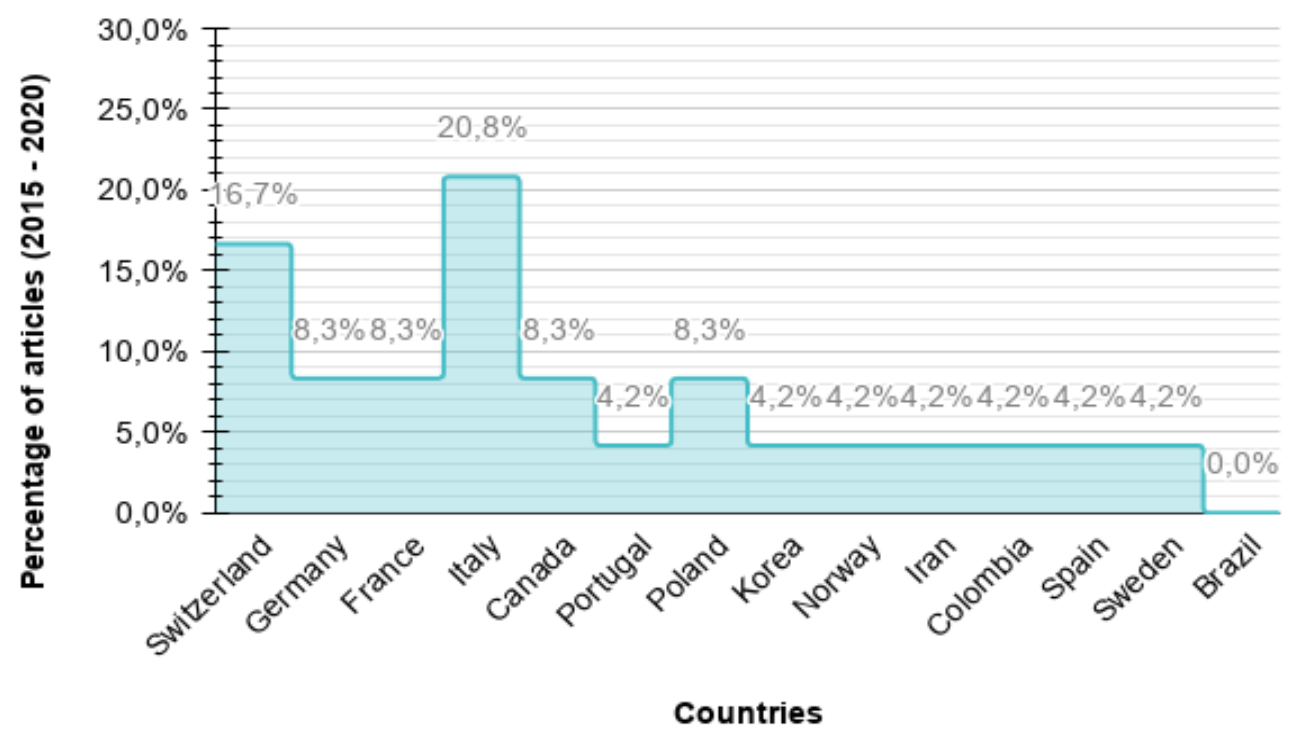

Fonte: Author's own 
Between 2015 and 2020, authors with the most publications were Samuel Brunner [9-11] and Jannis Wernery [9, 11], who state, based on their research, aerogel performance in density and thermal conductivity in the range of 65 to $230 \mathrm{~kg} / \mathrm{m}^{3}$ and 15 to $28 \mathrm{~mW} /$ (m.K). In parallel, other tests demonstrate that, to the detriment of thermal-acoustic and lightness properties, it is possible to achieve, satisfactory compressive strength in the concrete mixtures, with values between 3.0 and $23.6 \mathrm{MPa}$ [8].

On other hand, Figure 1 shows a comparison with traditional lightweight aggregates, commonly used in Brazil. It has found that aerogel has a great advantage, allowing to generate greater optimization of processes and performance of construction systems.

Figure 1. Table of physical properties of concrete with aerogel and traditional lightweight aggregate.

\begin{tabular}{|c|l|c|c|c|}
\hline Ref. & \multicolumn{1}{|c|}{ Aggregates } & $\boldsymbol{\rho}\left[\mathrm{kg} / \mathrm{m}^{3}\right]$ & $\boldsymbol{\Lambda}[\mathrm{W} /(\mathrm{m} . \mathrm{K})]$ & fck $[\mathrm{MPa}]$ \\
\hline$[8]$ & Aerogel & $730-1170$ & $0,160-0,370$ & $3,00-23,60$ \\
\hline$[12],[13]$ & Expanded Clay & $1571-1645$ & $0,610-0,770$ & $17,60-33,20$ \\
\hline$[6],[14]$ & Expanded Vermiculite & $380-640$ & $0,140-0,250$ & $0,24-1,19$ \\
\hline$[7]$ & Expanded Perlite & $352-800$ & $0,077-0,119$ & $0,82-3,44$ \\
\hline
\end{tabular}

Fonte: Author's own

In addition to technical analysis, it is known that there are different aerogel products on the market, using as roofs, planks, renderings, granules, translucent panels and vacuum insulation panels. As evidenced by [11], their uses within the construction environment are due to the fact that they are good thermal insulators, therefore, "(...) suitable for the refurbishment of heritage buildings where little space is available or where a thick insulation would alter the appearance of the building drastically. ". However, conversely, the authors reveal that "Monolithic aerogel has not found any commercial application in buildings so far, as it is rather brittle and cannot be efficiently produced in sizes exceeding a few centimeters".

Among the existing products, mentioned above, durability studies were carried out for vacuum insulation panels (VIP) with an aerogel core, which has an estimated useful life of more than 50 years [15], while for aerogel granules and the materials for blankets, can lead to deterioration when exposed to higher temperatures $\left(70{ }^{\circ} \mathrm{C}\right)$ and relative humidity (>90\%). Nevertheless, the authors suggest that for most typical building applications, this is not a concern [11].

Also at the literature it was found that the aerogel has low thermal conductivity [8, 9, 11], good insulation properties [16] and hydrophobicity [11], which is also dependent on the combination/proportion with other concrete and mortar inputs. Some research also demonstrates a significant impact on the resistance to water vapor diffusion [11], which means that the product thickness can be halved when compared to other conventional materials [11]. In addition, they are useful for application on windows due to the level of transparency and greater lightness [16].

On the other hand, some disadvantages are related to the production of dust in its handling and installation, when used as blankets, boards, and granules [11] and 
also due to the infrastructure limitation of some industrial sectors. The cost continues to be relatively high, therefore, some authors support that aerogel most economical way of production is to compact into boards or used as additives for renders [9]

\section{CONCLUSION}

Finally, based on all the data collected and evaluated, it is evident that the use and production of aerogel-based materials is still a challenge for the industry. The articles were focused on its thermal potential, returning its application to buildings only to establish an energy gain and sustainable. However, it has also been proven that it is possible to direct it to the manufacture of lightweight modular panels made of concrete, reaching acceptable values of compressive strength.

In this way, it is evident that Brazil, throughout its supply chain and scientific community, has a great opportunity to deepen and be a pioneer in this study, regarding South America. It is necessary to innovate and discover a new alternative way of materials technology to guarantee a higher level of productivity and quality in the Civil Construction Market.

\section{REFERENCES}

1 MARíN, Begoña. Como a China conseguiu erguer o hospital do coronavírus de Wuhan em 10 dias. El País, 03 feb. 2020. Icon Design. Available in: $<$ https://brasil.elpais.com/icon_design/2020-02-03/como-a-china-conseguiu-erguer-ohospital-do-coronavirus-de-wuhan-em-10-dias.html>. Access in: 30 july 2020.

2 CONSTRUÍDO EM 10 DIAS, HOSPITAL RECEBE PRIMEIROS PACIENTES COM CORONAVÍRUS NA CHINA; VEJA VÍDEO DA CONSTRUÇÃO. G1: Globo Notícias, 03 feb. 2020. Mundo. Available in: $<$ https://g1.globo.com/mundo/noticia/2020/02/03/construido-em-10-dias-hospitalrecebe-seus-primeiros-pacientes-com-coronavirus-na-china.ghtml>. Access in: 30 july 2020.

${ }^{3}$ CORONAVÍRUS: EM IMAGENS, A CONSTRUÇÃO DE HOSPITAL NA CHINA EM 10 DIAS. BBC, 03 feb. 2020. News. Available in: <https://www.bbc.com/portuguese/internacional-51354870>. Access in: 30 july 2020.

4 ASSOCIAÇÃO BRASILEIRA DE NORMAS TÉCNICAS. NBR 15575: Residential buildings - Performance. Rio de Janeiro. 2013.

${ }^{5}$ ARGILA EXPANDIDA, TIPO 0500. São Paulo: CINEXPAN - Indústria e Comércio de Argila Expandida Ltda. Ficha Técnica do Produto.

6 MACEDO, Nilson Luiz de Maia. Vermiculita Expandida: O Uso Da Vermiculita $\mathrm{Na}$ Construção Civil. Paraíba: TERRHA. 4 f. Ficha Técnica do Produto.

7 PERLITERMIC AF-100: Perlita Expandida. Rio Grande do Sul: Pervale Minerais. 2 f. Ficha Técnica do Produto. 
${ }^{8}$ FICKLER, Silvia et al. Development of high performance aerogel concrete. Energy Procedia, v. 78, p. 406-411, 2015.

9 WERNERY, Jannis et al. Aerobrick-An aerogel-filled insulating brick. Energy Procedia, v. 134, p. 490-498, 2017.

10 MASERA, Gabriele et al. Development of a super-insulating, aerogel-based textile wallpaper for the indoor energy retrofit of existing residential buildings. Procedia engineering, v. 180, p. 1139-1149, 2017.

${ }^{11}$ GANOBJAK, Michal; BRUNNER, Samuel; WERNERY, Jannis. Aerogel materials for heritage buildings: Materials, properties and case studies. Journal of Cultural Heritage, v. 42, p. 81-98, 2020.

12 MORAVIA, Weber Guadagnin; GUMIERI, Adriana Guerra; VASCONCELOS, Wander Luiz. Efficiency factor and modulus of elasticity of lightweight concrete with expanded clay aggregate. Revista IBRACON de Estruturas e Materiais, v. 3, n. 2, p. 195-204, 2010.

${ }^{13}$ ANGELIN, Andressa Fernanda; LINTZ, Rosa Cristina Cecche; BARBOSA, Luisa Andreia Gachet. Uso da argila expandida e sílica ativa no melhoramento dos desempenhos mecânicos, físicos e térmicos de concretos leves estruturais. Matéria (Rio de Janeiro), v. 22, 2017.

14 PASSOS, P. M.; CARASEK, H. Argamassas com resíduos para revestimento isolante térmico de parede pré-moldada de concreto. Cerâmica, v. 64, n. 372, p. 577588, 2018.

${ }^{15}$ GONÇALVES, Márcio et al. A review of the challenges posed by the use of vacuum panels in external insulation finishing systems. Applied Energy, v. 257, p. 114028, 2020.

16 ROStAM, N. Gholami; MAHDAVINEJAD, M. J.; ROSTAM, M. Gholami. Commercializing usage of nano-insulating materials in building industry and future architecture. Procedia Materials Science, v. 11, p. 644-648, 2015. 